\title{
Invest in Canadian Synthetic Biology to Meet Commitments to Sustainable Development and Support Economic Recovery
}

\section{Brendan Grue ${ }^{1,2}$, Samir Hamadache ${ }^{1,3}$, Dhanyasri} Maddiboina ${ }^{1,4}$, Benjamin Scott ${ }^{1,5}$

${ }^{1}$ SynBio Canada

2 Dalhousie University, Faculty of Medicine, Halifax, NS, Canada

3 Western University, Department of Biochemistry, London, ON, Canada

4 McMaster University, Department of Chemical Engineering. Hamilton, ON, Canada

${ }^{5}$ Concordia University, Centre for Applied Synthetic Biology, Montreal, QC, Canada

All authors contributed equally

https://doi.org/10.38126/ISPG180106

Corresponding author: ben.scott@synbiocanada.org

Keywords: synthetic biology; Canada; sustainable development goals; clean technology; biotechnology

Executive Summary: Canadian post-COVID-19 economic recovery efforts have been framed around values aligned with Canada's commitments to the United Nations Sustainable Development Goals (SDGs), primarily concerning environmental sustainability. The field of synthetic biology (synbio) offers many innovative ways to achieve these goals while growing the economy. Here, we discuss the opportunity for Canada to become a leader in clean technology applications of synbio. Investments in synthetic biology, which has traditionally been underfunded compared to other countries, will have beneficial impacts on the environment while driving Canada's post-pandemic economic recovery.

\section{Background}

Canada is a signatory to the UN Sustainable Development Goals (SDGs), which aim to address the environmental integrity of our planet and the welfare of its inhabitants (United Nations 2020). Although Canada officially recognized climate change decades ago (Maxwell et al. 1997), Canadian emissions continue to rise (Government of Canada 2020a), and global progress towards addressing the SDGs has been limited (Nature 2020). To address the economic impact of the COVID-19 pandemic, which caused Canada's GDP to drop by a record $5.1 \%$, efforts by both the federal government and the private sector have prioritized sustainability as a guiding principle (Reuters 2021; Task Force For a Resilient Recovery 2020; Lindeman 2020; ISED 2020). In this memo, we recommend investing in synthetic biology as a technological tool to meet Canada's commitments to the UN SDGs along with stimulating economic recovery.
Synthetic biology (synbio) represents a maturation of the fields of genetic engineering and biotechnology. Synthetic biologists design and build biological systems to solve problems. The time for investing in synthetic biology is now, and this is only made more evident by the current public health crisis. Synbioenabled technologies are on the frontline of addressing the COVID-19 pandemic, ranging from novel diagnostic tests to new types of vaccines (Cumbers 2020; Kitney et al. 2021). Synbio will be critical in post-pandemic economic recovery by ushering in the "biorevolution," which is estimated to have a US\$4-trillion impact globally within twenty years (McKinsey \& Company 2020). With more biomass per capita than any other country (Stephen \& Wood-Bohm 2016), which can be converted into valuable chemicals using engineered microbes (French 2009), Canada is competitively positioned to take advantage of the biorevolution. Canadian regulations on biotechnology are more permissive 
than in Europe, making it easier for innovators and investors to put biology to work on environmental challenges (Lassoued et al. 2018). Canada's liberal immigration policy is an opportunity for Canada to invest in the creation of skilled jobs to retain and attract competitive talent in synbio (Reiche 2019). Synthetic biology should be considered a critical technological pillar of Canada's economic recovery strategies, including those of the Industry Strategy Council and the Task Force for a Resilient Recovery. As well, synbio provides a "game-changing opportunity" to achieve various SDGs while driving economic growth (French 2019; Sworder \& Zhang 2018):

SDG \#6: Micropollutants in water are traditionally detected using expensive and laborious instrumentbased methods. Synbio-based biosensors provide a far cheaper and simpler alternative (Ausländer et al. 2017; Bereza-Malcolm et al. 2015; FREDsense Technologies 2020; Hicks et al. 2020; Kim et al. 2018; Roggo \& van der Meer 2017).

SDG \#7, 11, 12, 13: Synthetic biologists are engineering organisms to manufacture vital resources, including biofuels, pigments, drug precursors, biodegradable plastics, and "smart" materials which are able to self-assemble and selfrepair (Zhou et al. 2018; Darvishi et al. 2018; Le Feuvre \& Scrutton 2018).

SDG \#8, 9, 11: Biocatalysts can convert greenhouse gases from industrial processes into valuable products like rubber and feedstock chemicals (Newlight 2020; BIO 2013; Zhu et al. 2019). Compared with chemical catalysts, biocatalysts produce high-value chemicals at higher yields with reduced costs and waste. 1

In a survey conducted with 653 Canadian companies, half said they would invest more in clean technology if they could overcome a lack of capital budget or financing (Wichmann 2014). Synbio offers a solution to these economic barriers, with a demonstrated ability to attract funding. In 2020 alone, global private investment in synbio totalled US\$7.8B, up from US\$4B in 2018 and US\$300M in 2010 (Wisner 2021). The global market for products enabled by synbio is expected to grow from US\$2.7B (2019) to US\$9.9B (2024) at a compound annual growth rate of $30 \%$, three times faster than the global robotics market (BCC Publishing 2019).

In this memorandum, we outline Canada's current state of investment into synbio and clean technology, and we recommend a set of strategies for Canada to harness synbio towards meeting its commitments to the UN Sustainable Development Goals.

\section{Current political and funding status}

Canada is highly reliant on non-renewable resource extraction, with oil and gas making up $6 \%$ of the national GDP (Government of Canada 2019; Natural Resources Canada 2020). Consequently, in 2019, Canada had the third-highest $\mathrm{CO}_{2}$ emissions per capita among G20 nations (Enerdata 2020). A forward-thinking national strategy is required to transition Canada towards a circular economy, which aims to extend product lifetimes and keep resources in continuous use by creating value from waste.

In 2017, the Canadian government invested US $\$ 1.7 \mathrm{~B}$ into clean technology research and commercialization (ISED Canada 2018). While the federal government has recognized biotechnology's potential to address climate change, the funding of clean technologies has not reflected this, which has instead focused on improving traditional manufacturing, oil and gas, and renewable energy technologies (Health Canada 2017; Natural Resources Canada 2020; Government of Canada 2020b; SDTC 2020). Encouragingly, a recent investment of US\$11M to commercialize industrial applications of clean biotechnology represents a new funding direction (BIC 2020). However, before new technologies can be commercialized, fundamental research and training must be financially supported.

Unlike Australia, the USA, the UK, Germany, China, Finland, and Singapore, Canada has not yet funded a national strategy for synbio research and training (Gray 2018; Tong and Zhao 2016; Synthetic Biology Leadership Council 2016; Raffler 2018; Pei et al 2011; Penttilä 2017; NRF Singapore 2020). The National Engineering Biology Steering Committee has recently outlined such a strategy, which highlights how synbio could revolutionize many sectors of the Canadian economy, but funding has yet to be dedicated to support the strategy (Can-DESyNe 2020).

\footnotetext{
${ }^{1}$ Refer to Appendix I for the full list of SDGs.
} 
Funding from the primary federal grant agencies in Canada (the "Tri-Agency": CIHR, NSERC, SSHRC), has not kept pace with the growing private sector enthusiasm for synbio (Wisner 2021). Between 2010 and 2019, median Tri-Agency funding for Canadian synbio research was US\$7.3M/year, with only US\$2.8M awarded in 2019 (Cognit.ca 2021) (Figure 1). Genome Canada funding is not included in these data (US $\$ 137 \mathrm{M} /$ year), which is applied to many fields including but not limited to synbio (Genome Canada 2020). For comparison, the US aggressively funded synbio research beginning in 2008, with an average of US\$136M/year of public funding (Synthetic Biology Project 2015), while the UK has invested US\$80M/year (Synthetic Biology Leadership Council 2016). Based on 2019 GDP, the US economy is $\sim 12-$ times larger than Canada's, and the UK's is $~ 1.6$-times larger. Australia, which has a similar sized economy to Canada and is also reliant on resource extraction, invested US $\$ 10 \mathrm{M}$ towards synbio research in 2016 , which expanded to a US $\$ 31 \mathrm{M}$ research portfolio by 2018 (Vickers 2018).

Notably, two Canadian universities in the past five years have received federal funding for synbio laboratory infrastructure (Centre for Applied Synthetic Biology at Concordia; SynBridge at Lethbridge), and new training programs have been started at three Canadian universities (Concordia, Ottawa, and Western). The recently launched NRC Challenge program also includes funding for therapeutic applications of synbio (National Research Council Canada 2019). These examples are encouraging and buoyed by significant interest from students (Western University 2020), but they do not represent a concerted national effort to advance synbio, as seen in other countries.

\section{Policy recommendations}

We recommend a set of responses that will establish Canada as a leader in harnessing synbio for clean technology:

\section{i. Strengthen the synthetic biology ecosystem in Canada}

There is an urgent need to develop synbio capabilities in Canada to remain globally competitive. A significant, broad, and flexible investment is needed to retain and attract talent and spur innovation. An ecosystem-focused approach to increasing Canada's synbio capabilities, like the National Industrial

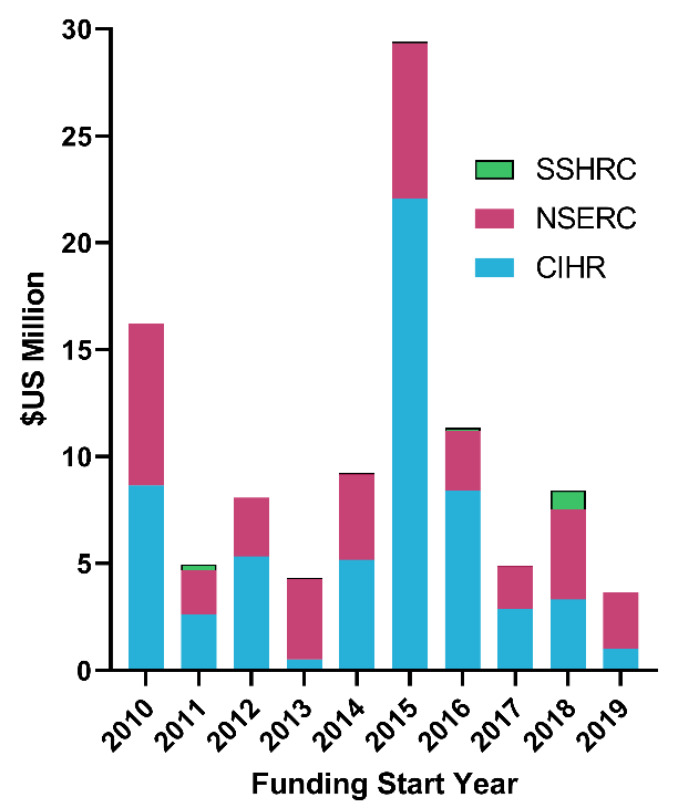

Figure 1: Tri-Agency funding of synthetic biology research in Canada. Funded research described as "synthetic biology" by the grant awardee is reported. Research that may be considered synthetic biology but was not described as such by the grant awardee is not included. SSHRC: Social Sciences and Humanities Research Council; NSERC: Natural Sciences and Engineering Research Council; CIHR: Canadian Institutes of Health Research. Data retrieved from cognit.ca January 27, 2021.

Symbiosis Programme Canada initiative, would maximize the impact of such an investment (NISP Canada 2019). This effort should include support for research and training, seed capital for Canadian synbio startups, coordination across geographic regions, and increased public engagement to improve understanding of biotechnology. A new ecosystem initiative, called Can-DESyNe, promises to develop and steer such a coordinated strategy (Can-DESyNe 2020), but its success depends on significant contributions from both the public and private sectors.

We recommend at least US $\$ 50 \mathrm{M} /$ year of public funds be invested in synbio, which is based on the relative size of Canada's GDP to the UK's and the amount the UK has already invested in synbio (Synthetic Biology Leadership Council 2016).

Based on the transformative potential of synbio across many industries and sectors, initial rounds of funding should support synbio research broadly and not be limited to clean technology applications. This diversified approach will result in infrastructure and 
tools that can be used for many applications, such as automated laboratories and new model organisms (Adams 2016). Vital synbio training programs will build a skilled workforce to utilize these resources. The scientific, physical, and human resources made possible by this general funding can then be strategically leveraged towards achieving the SDGs.

\section{ii. Fund synbio clean technologies for environmental remediation (reactive response)}

Based on the immediate need for new solutions to deal with the environmental impact of human activity, we recommend that the Government of Canada invest in the private-sector uptake of synbio technologies that focus on remediation.

Synbio startup companies already enable the sensing, remediating, and managing of pollutants, such as FREDsense, a Canadian-based startup that engineers bacteria to detect heavy metals in water (FREDsense Technologies 2020). There is also extensive research in using microbes for cleaning up tailings ponds resulting from the Alberta oilsands (Foght et al. 2017; Khamar et al. 2015), as well as utilizing bacteria for cleaner oil and ore extraction (Xu et al. 2011; Seifelnassr et al. 2013). Engineered microbes also hold promise for capturing and recycling carbon dioxide (Singh et al. 2019).

Prioritizing remedial solutions will accelerate Canadian innovation in synbio by capitalizing on the growing clean technology market, which is partly created by public policies aimed at meeting environmental goals (Elgie \& Brownlee 2017). Incentives for meeting government regulations and corporate social responsibility, paired with the improved return on investment that synbio promises over other clean technologies (Carbon Brief 2019), will drive commercialization. According to the pioneering synbio venture capitalist, Arvind Gupta, Generation $\mathrm{Z}$ and Millennial consumers are increasingly willing to pay a premium for ethical business (Draper 2020). These same consumers are also increasingly open to foods produced using genetic technologies compared to Generation $\mathrm{X}$ and Baby Boomers (Ketchum 2019), indicating an increasingly positive public perception of biotechnology which will complement increased investments in this sector.
This recommendation seeks to mitigate the environmental impacts of industrialization without fully addressing the source of the impact. Nevertheless, investing in bioremediation technologies will develop Canada's public and private capabilities to pursue more disruptive innovations.

\section{iii. Fund transformative synbio clean technologies} (proactive response)

An incredible number of biosynthetic pathways exist in the natural world that can be harnessed using synbio to generate valuable products, including industrial chemicals and food (Smanski et al. 2016). Synbio therefore holds the potential to move the Canadian economy away from its reliance on resource extraction, and thus reduce the need for environmental remediation. Further advances in synbio will accelerate the global move towards circular economies, such as using synbio-enabled technologies to convert waste and emissions into something valuable (Savini 2019).

Using engineered biological systems to reduce and recycle waste-and ultimately replace unsustainable manufacturing processes-is one of the great promises of synbio. Examples already exist, such as using yeast to produce palm oil (Kalyanaraman 2018) or engineering cyanobacteria to produce high-value chemicals from greenhouse gases (Fabris et al. 2020). Another transformative synbio technology comes from Pivot Bio, which has harnessed soil microbes to reduce the need for nitrogen fertilizers (Pivot Bio 2020). The production and application of nitrogen fertilizers cause significant greenhouse gas emissions (Carlson et al. 2016) and directly contribute to toxic algal blooms in the Great Lakes (Mezzacapo 2018). Funding the continued exploration and design of biosynthetic pathways, and non-standard microbial chassis to host these pathways, is necessary before they can be applied on economically-relevant scales (Brietling et al. 2016).

Synbio also has many applications in the food industry, including the production of animal-free meat and dairy products, and flavouring for plantbased burgers (Bomgardner 2020). Crop and livestock production account for $10 \%$ of greenhouse gas emissions in Canada (Government of Canada 2020c), thus the adoption of synbio-enabled animalfree food may help to lower these emissions. Funding the growth and adoption of similar technologies in 
Canada is also an opportunity to ensure food security, as climate change has the potential to disrupt traditional food supplies globally (Wheeler \& von Braun 2013).

This proactive approach aims to harness the creative potential of new synbio technologies, enabling Canada to become a leader in technologies that can help achieve the UN SDGs, while driving job creation. This recommendation can be understood as an appeal for public and private investment in higherrisk, higher-reward applications of synbio.

\section{Avoiding potential pitfalls}

As many of these engineered biological systems are intended to be applied to solve real-world problems, ethics and biosafety must be incorporated in every synbio training curriculum, academic lab, and company. Environment and Climate Change Canada should also be involved in the coordination and management of synbio funding regarding environmental applications.

Biotechnology commercialization is challenging, where a "valley of death" is perceived to exist between academic results and a successful biotech company (Moran 2007). In cases where research is intended to be commercialized, business training to develop compelling market validations would help to maximize the probability of commercial success. Early-stage investment of companies is also required, which could be modelled on the USA's successful Small Business Innovation Research (SBIR) program (SBIR 2020), or joined with the efforts of Sustainable Development Technology Canada (SDTC 2020). These programs provide non-dilutive seed funding for small businesses, including research into clean technology.

Canadian private investors are known to be more risk-averse and have been hesitant to capitalize on

\section{References}

Adams, Bryn L. 2016. "The Next Generation of Synthetic Biology Chassis: Moving Synthetic Biology from the Laboratory to the Field." ACS Synthetic Biology 5(12): 1328-30. https://doi.org/10.1021/acssynbio.6b00256

Ausländer, Simon, David Ausländer, and Martin Fussenegger. 2017. "Synthetic Biology-the Synthesis of Biology." Angewandte Chemie International Edition 56 (23): 6396-6419. https://doi.org/10.1002/anie.201609229 synbio opportunities (Goodsell 2016; Kinder \& Robbins 2018). Initial government investment would reduce the financial risk and increase confidence from the private sector. Importantly, synbio presents a more favourable risk/reward ratio than previous generations of biotechnology, due to rapid advancements in the tools available (El Karoui et al. 2019). Therefore, the cost and time required to build a synbio-based company has been significantly reduced, as evidenced by the hundreds of synbio companies in the US and UK established in the past ten years (Clarke \& Kitney 2020).

Canada must be cautious about investing only in remediation-focused technology, which would maintain an environmental status quo. As well, the benefit of new synbio technologies is not always immediately obvious. For example, engineering bacteria to clean a lake has a direct positive benefit, which first needs genetic tools to control complex microbiomes. The latter requires more investment in the fundamental research stage, which would involve a longer delay before the technologies become marketable. As such, to achieve the third recommendation, a significant portion of the funding committed to synbio clean technology should go towards fundamental research, and not only to immediately marketable technologies.

Synbio has the potential to transform many sectors and provide solutions to environmental and climate change challenges. We recommend an ecosystemfocused federal investment, with support for using synbio to remediate the environment (reactive) as well as improve or replace wasteful industries (proactive). In doing so, Canada will position itself as a leader in synbio, meeting its commitments to the UN Sustainable Development Goals while accelerating its post-pandemic economic recovery.

\footnotetext{
Bereza-Malcolm, Lara Tess, Gülay Mann, and Ashley Edwin Franks. 2015. "Environmental Sensing of Heavy Metals through Whole Cell Microbial Biosensors: A Synthetic Biology Approach." ACS Synthetic Biology 4 (5): 535-46. https://doi.org/10.1021/sb500286r
} 
BIC. "BIC Receives \$15M Contribution from FedDev Ontario." Bioindustrial Innovation Canada, February 14, 2020. https://www.bincanada.ca/singlepost/2020/02/13/BIC-receives-15Mcontribution-from-FedDev-Ontario

Bomgardner, Melody M. (2020). "Can start-ups make us love animal-free dairy?" Chemical \&Engineering News 98 (38): 27-30.

https://pubs.acs.org/doi/10.1021/cen-09838cover

Can-DESyNe. "Engineering Biology: A platform technology to fuel multi-sector economic recovery and modernize biomanufacturing in Canada." National Engineering Biology Steering Committee, November 2020. https://www.candesyne.ca/white-paperengineering-biology

Carlson, Kimberly M., James S. Gerber, Nathaniel D. Mueller, Mario Herrero, Graham K. Macdonald, Kate A. Brauman, Petr Havlik, et al. 2016. "Greenhouse Gas Emissions Intensity of Global Croplands." Nature Climate Change 7 (1): 63-68. https://doi.org/10.1038/nclimate3158

Centre for Applied Synthetic Biology. "Centre for Applied Synthetic Biology.” Accessed April 15, 2020. https://www.concordia.ca/research/casb.html

Clarke, Lionel, and Richard Kitney. "Developing synthetic biology for industrial biotechnology applications." Biochemical Society Transactions. February 28, 2020. https://dx.doi.org/10.1042\%2FBST20190349

Cognit.ca. "Access expertise, facilities and IP at Canada's post-secondary institutions." Accessed January 27, 2021. https://cognit.ca/en/

Cumbers, John. "The Synthetic Biology Companies Racing To Fight Coronavirus." Forbes. Forbes Magazine, February 10, 2020.

https://www.forbes.com/sites/johncumbers/20 20/02/05/seven-synthetic-biology-companiesin-the-fight-against-coronavirus/\#6d80b51c16ef

"Current Uses of Synthetic Biology for Renewable Chemicals, Pharmaceuticals, and Biofuels." BIO, 2013.

https://www.bio.org/sites/default/files/legacy/ bioorg/docs/Synthetic-Biology-and-EverydayProducts-2012.pdf

Darvishi, Farshad, Mehdi Ariana, Eko Roy Marella, and Irina Borodina. 2018. "Advances in Synthetic Biology of Oleaginous Yeast Yarrowia Lipolytica for Producing Non-Native Chemicals." Applied Microbiology and Biotechnology 102 (14): 592538. https://doi.org/10.1007/s00253-018-9099-x
"Direct CO2 Capture Machines Could Use 'a Quarter of Global Energy' in 2100." Carbon Brief. Carbon Brief Ltd., July 22, 2019.

https://www.carbonbrief.org/direct-co2capture-machines-could-use-quarter-globalenergy-in-2100

Draper, Adam, Episode 94: Funding Biotech with Conscious Capitalism (to Save the World) - with Arvind Gupta. Boost VC, podcast audio, August $27,2020$. https://theboostvcpodcast.simplecast.com/episo des/ep-94-arvind-gupta-of-the-mayfield-fundpySUZedH

Elgie, Stewart, and Michelle Brownlee. "Accelerating Clean Innovation in Canada." Smart Prosperity Institute, April 2017. https://institute.smartprosperity.ca/sites/defaul t/files/acceleratingcleaninnovationincanada.pdf

El Karoui, Meriem, Monica Hoyos-Flight, and Liz Fletcher et al. "Future Trends in Synthetic Biology-A Report." Frontiers in Bioengineering and Biotechnology. August 17, 2019. https://doi.org/10.3389/fbioe.2019.00175

Goodsell, David. "Are Canadian investors too cautious?" Advisor's Edge. July 26, 2016. https://www.advisor.ca/investments/marketinsights/are-canadian-investors-too-cautious

Enerdata, "CO2 emissions from fuel combustion." Global Energy Statistical Yearbook 2020. July 9, 2020. https://yearbook.enerdata.net/co2-fuelcombustion/CO2-emissions-data-from-fuelcombustion.html

Fabris, Michele, Raffaela M. Abbriano, Mathieu Pernice, Donna L. Sutherland, Audrey S. Commault, Christopher C. Hall, Leen Labeeuw, et al. 2020. "Emerging Technologies in Algal Biotechnology: Toward the Establishment of a Sustainable, Algae-Based Bioeconomy." Frontiers in Plant Science 11. https://doi.org/10.3389/fpls.2020.00279

Feuvre, Rosalind A Le, and Nigel S Scrutton. 2018. "A Living Foundry for Synthetic Biological Materials: A Synthetic Biology Roadmap to New Advanced Materials." Synthetic and Systems Biotechnology 3 (2): 105-12. https://doi.org/https://doi.org/10.1016/j.synbi $\underline{0.2018 .04 .002}$

Foght, Julia M., Lisa M. Gieg, and Tariq Siddique. 2017. "The Microbiology of Oil Sands Tailings: Past, Present, Future." FEMS Microbiology Ecology 93 (5). https://doi.org/10.1093/femsec/fix034

"FREDsense Technologies: Portable Sensors: Water Chemistry Analysis." FREDsense. Accessed April 15, 2020. https://www.fredsense.com/ 
French, Christopher E. 2009. "Synthetic biology and biomass conversion: a match made in heaven?" Journal of the Royal Society Interface, 6: S547S558 https://doi.org/10.1098/rsif.2008.0527.focus

French, K E. 2019. "Harnessing Synthetic Biology for Sustainable Development." Nature Sustainability 2 (4): 250-52. https://doi.org/10.1038/s41893019-0270-x.

“Genome Canada: Annual Report 2019-2020." 2020. Genome Canada. https://www.genomecanada.ca/sites/default/fil es/genomecanada-annualreport-en-web.pdf

"Get the Sustainable Development Goals Back on Track." 2020. Nature 577 (7788): 7-8. https://doi.org/10.1038/d41586-019-03907-4

Government of Canada. "Canada's actions to reduce emissions." Canada's Climate Plan, December 6, 2019.

https://www.canada.ca/en/services/environme nt/weather/climatechange/climate-plan/reduceemissions.html

Government of Canada. "Greenhouse gas emissions" Environment and Climate Change, January 2, 2020a. https://www.canada.ca/en/environmentclimate-change/services/environmentalindicators/greenhouse-gas-emissions.html

Government of Canada. "The Low Carbon Economy Fund." March 10, 2020b.

https://www.canada.ca/en/environmentclimate-change/services/climate-change/lowcarbon-economy-fund.html

Government of Canada. "Greenhouse gases and agriculture." January 30, 2020c.

https://www.agr.gc.ca/eng/agriculture-and-theenvironment/agricultural-practices/climatechange-and-agriculture/greenhouse-gases-andagriculture/?id=1329321969842

Gray, Peter, Sure Meek, Paul Griffiths, Joseph Trapani, Ian Small, Claudia Vickers, Catherine Waldby, and Rebecca Wood. 2018. "Synthetic Biology in Australia: An Outlook to 2030." Report for the Australian Council of Learned Academies. www.acola.org.au

Health Canada. "Canada's Biotechnology Strategy." Biotechnology: Our Role, August 29, 2017. https://www.canada.ca/en/healthcanada/services/science-research/emergingtechnology/biotechnology/role/canadabiotechnology-strategy.html

Hicks, Maggie, Till T Bachmann, and Baojun Wang. 2020. "Synthetic Biology Enables Programmable CellBased Biosensors." ChemPhysChem 21 (2): 13244. https://doi.org/10.1002/cphc.201900739
ISED Canada. "Report from Canada's Economic Strategy Tables: Clean Technology.” Economic Strategy Tables, October 4, 2018. https://www.ic.gc.ca/eic/site/098.nsf/eng/0002 3.html

ISED Canada. "Industry Strategy Council." Innovation for a Better Canada, August 20, 2020.

https://www.ic.gc.ca/eic/site/062.nsf/eng/h 00 117.html

Kalyanaraman, Srividya. "This Boston Startup Is Trying to Solve the World's Palm Oil Problem." americaninno.com. American City Business Journals, September 4, 2018. https://www.americaninno.com/boston/bostonstartup/this-boston-startup-is-trying-to-solvethe-worlds-palm-oil-problem/

Ketchum. "A Rising Generation of Food Consumers Is More Open to New Food Technology, Says Ketchum Study." Ketchum, Inc. November 1, 2019. https://www.ketchum.com/news/foodtechnology-trends-a-rising-generation-of-foodconsumers-is-more-open-to-new-foodtechnology-says-ketchum-study/

Khamar, Z., A. Makhdoumi-Kakhki, and M.h. Mahmudy Gharaie. 2015. "Remediation of Cyanide from the Gold Mine Tailing Pond by a Novel Bacterial CoCulture." International Biodeterioration \& Biodegradation 99: 123-28. https://doi.org/10.1016/j.ibiod.2015.01.009

Kim, Hyun Ju, Haeyoung Jeong, and Sang Jun Lee. 2018. "Synthetic Biology for Microbial Heavy Metal Biosensors." Analytical and Bioanalytical Chemistry 410 (4): 1191-1203. https://doi.org/10.1007/s00216-017-0751-6

Kinder, Jeff, and Mark Robbins. "The Present and Future State of Synthetic Biology in Canada." The Institute on Governance, May 1, 2018. https://www.genomecanada.ca/sites/default/fil es/the-present-and-future-state-of-syntheticbiology-in-canada.pdf

Kitney, Richard, Jennifer Bell, and Jim Philp. 2021. "Build a Sustainable Vaccines Industry with Synthetic Biology." Trends in Biotechnology: in press. https://doi.org/10.1016/i.tibtech.2020.12.006

Lassoued, Rim, Stuart J. Smyth, Peter W. B. Phillips, and Hayley Hesseln. 2018. "Regulatory Uncertainty Around New Breeding Techniques." Frontiers in Plant Science 9 (1219). https://doi.org/10.3389/fpls.2018.01291

Lindeman, Tracey. "Canada: departure of finance minister suggests Trudeau will pursue 'green' recovery plan." The Guardian. August 18, 2020 https://www.theguardian.com/world/2020/aug $\not 18 /$ canada-justin-trudeau-bill-morneau-covid19-green-recovery 
McKinsey \& Company. "The Bio Revolution: Innovations transforming economies, societies, and our lives." May 13, 2020.

https://www.mckinsey.com/industries/pharmac euticals-and-medical-products/our-insights/thebio-revolution-innovations-transformingeconomies-societies-and-our-lives

Maxwell, Barrie, Nicola Mayer, Grace Koshida, and Roger Street. "The Canada Country Study: Climate Impacts and Adaptation Canada," Environment Canada. November 1997.

Mezzacapo, Michael. "Green Without Envy: Great Lakes Drown in Excessive Nutrient Pollution." International Joint Commission. International Joint Commission Great Lakes Regional Office, March 8, 2018. https://www.ijc.org/en/greenwithout-envy-great-lakes-drown-excessivenutrient-pollution

Moran, Nuala. 2007. "Public Sector Seeks to Bridge Valley of Death." Nature Biotechnology 25 (3): 266-66. https://doi.org/10.1038/nbt0307-266

Natural Resources Canada "Current Investments." Funding Opportunities. March 30, 2020. https://www.nrcan.gc.ca/science-data/fundingpartnerships/funding-opportunities/currentinvestments/21146

Natural Resources Canada. "Energy and the Economy." Energy Facts. March 30, 2020. https://www.nrcan.gc.ca/science-data/dataanalysis/energy-data-analysis/energyfacts/energy-and-economy/20062

National Research Council Canada. "Challenge Programs." March 26, 2019.

https://nrc.canada.ca/en/researchdevelopment/researchcollaboration/programs/challenge-programs

NISP Canada. "Advancing a Circular Economy in Canada: National Industrial Symbiosis Program (NISP®) Canada Pilot Project, Metro Vancouver \& Greater Edmonton." June 15, 2019.

https://nispcanada.ca/wpcontent/uploads/2019/08/NISPPerformanceRep ort-Pilot-FINAL.pdf

NRF Singapore. "Synthetic Biology R\&D Programme". Accessed April 15, 2020. https://www.nrf.gov.sg/programmes/syntheticbiology-r-d-programme

Pei, Lei, Markus Schmidt, and Wei Wei. 2011. "Synthetic Biology: An Emerging Research Field in China." Biotechnology Advances 29 (6): 804-14. https://doi.org/10.1016/j.biotechadv.2011.06.00 $\underline{8}$

Pivot Bio. "Pivot Bio PROVEN." Accessed April 15, 2020. https://www.pivotbio.com/product
Penttilä, Merja. 2017. "Synthetic biology as an enabler of sustainable bioeconomy - A roadmap for Finland", Living Factories Project.

Raffler, Nikolai. 2018. "Synthetic Biology Position Paper", Permanent Senate Commission on Genetic Research of the German Research Foundation.

Reiche, Sebastian. 2019. "From Brain Drain to Brain Gain: The Case of Canada".

https://blog.iese.edu/expatriatus/2019/04/05/f rom-brain-drain-to-brain-gain-the-case-ofcanada/

Reuters. 2021. "Canada's economy suffered biggest GDP drop ever in 2020, early estimate shows." Accessed January 30, 2021.

https://financialpost.com/news/economy/canad a-economy-sees-biggest-gdp-drop-ever-in-2020november-gdp-beats

"Robotics: Technologies and Global Markets" v. ENG001F. 2019. BCC Publishing.

https://www.bccresearch.com/marketresearch/engineering/robotics.html

Savini, Frederico. 2019. "The economy that runs on waste: accumulation in the circular city." Journal of Environmental Policy \& Planning 21 (6). https://doi.org/10.1080/1523908X.2019.16700 $\underline{48}$

SDTC. "Sustainable Development Technology Canada: Active Projects." Sustainable Development Technology Canada, 2020. https://www.sdtc.ca/en/projects

Seifelnassr, Ahmed A. S., and Abdel-Zaher M. Abouzeid. 2013. "Exploitation of Bacterial Activities in Mineral Industry and Environmental Preservation: An Overview." Journal of Mining 2013: 1-13. https://doi.org/10.1155/2013/507168

Singh, Jyoti, and Dolly Wattal Dhar. 2019. "Overview of Carbon Capture Technology: Microalgal Biorefinery Concept and State-of-the-Art." Frontiers in Marine Science 6. https://doi.org/10.3389/fmars.2019.00029

Smanski, Michael J, Zhou, Hui, Claesen, Jan, Shen, Ben, Fischbach, Michael, and Christopher A. Voigt. 2016. "Synthetic biology to access and expand nature's chemical diversity." Nature Reviews Microbiology 14(3): 135-149. https://doi.org/10.1038/nrmicro.2015.24

Stephen, Jamie, and Susan Wood-Bohm. February 2016. Biomass Innovation: Canada's Leading Cleantech Opportunity for Greenhouse Gas Reduction and Economic Prosperity. https://www.nrcan.gc.ca/sites/www.nrcan.gc.ca /files/energy/energy-resources/CCEMC Biomass Innovation.pdf 
"Sustainable Development Goals: Sustainable Development Knowledge Platform." United Nations. Accessed April 15, 2020. https://sdgs.un.org/goals

Sworder, Chris, and Leo Zhang. "2018 Global Cleantech 100 Report." San Francisco, CA: Cleantech Group, 2018.

SynBridge. "Alberta RNA Research and Training Institute." Synthetic Biology Maker Space | Centres \& Institutes. Accessed April 15, 2020. https://www.uleth.ca/research/centresinstitutes/alberta-rna-research-and-traininginstitute/synbridge-synthetic-biology-makerspace

"Synthetic Biology: Global Markets." BCC Publishing, 2020. https://www.bccresearch.com/marketresearch/biotechnology/synthetic-biologyglobal-markets.html

Synthetic Biology Project. "U.S. Trends in Synthetic Biology Research Funding." September 15, 2015. https://web.archive.org/web/20191001105916 /http://www.synbioproject.org/publications/u.s -trends-in-synthetic-biology-research-funding/

"Synthetic Biology Leadership Council." GOV.UK. 2016. Accessed April 15, 2020. https://www.gov.uk/government/groups/synth etic-biology-leadership-council

Task Force for a Resilient Recovery. "Preliminary Report". July 2020. https://www.recoverytaskforce.ca/wpcontent/uploads/2020/07/TFRR-PreliminaryReport-Jul-2020.pdf

Tong, Si, and Huimin Zhao. 2016. "A Brief Overview of Synthetic Biology Research Programs and Roadmap Studies in the United States." Synthetic and Systems Biotechnology 1 (4): 258-64. https://doi.org/10.1016/i.synbio.2016.08.003

uOttawa. "Honours BSc in Biochemistry - Synthetic Biology Option (120 units)." February 11, 2021. https://science.uottawa.ca/en/programs-ofstudy/undergraduate-studies/bsc-honours-specsynthetic-biochemistry-biology-120cr
Vickers, Claudia. "The Synthetic Biology Revolution Is Now - Here's What That Means." CSIROscope, September 5, 2018. https://blog.csiro.au/thesynthetic-biology-revolution-is-now-heres-whatthat-means

Western University. "Synthetic Microbial Genomes @ Western [SynGenMicrobes@Western]." Accessed April 15, 2020.

https://www.uwo.ca/facultyrelations/academic planning/idi/synthetic microbial genomes.html

Wheeler, Tim, and Joachim von Braun. 2013. "Climate Change Impacts on Global Food Security." Science 341 (6145): 508-513. https://science.sciencemag.org/content/341/61 $\underline{45 / 508}$

Wichmann, Lisa. "Cleantech Directions 2014." Cleantech Canada, 2014.

Wisner, Stephanie. "Synthetic Biology Investment Reached a New Record of Nearly $\$ 8$ Billion in 2020 - What Does This Mean For 2021?" Synbiobeta, January 27, 2021. https://synbiobeta.com/synthetic-biologyinvestment-set-a-nearly-8-billion-record-in2020-what-does-this-mean-for-2021/

$\mathrm{Xu}$, Yaohui, and Mang Lu. 2011. "Microbially Enhanced Oil Recovery at Simulated Reservoir Conditions by Use of Engineered Bacteria." Journal of Petroleum Science and Engineering 78 (2): 233-38. https://doi.org/10.1016/i.petrol.2011.06.005

Zhou, Yongjin J, Eduard J Kerkhoven, and Jens Nielsen. 2018. "Barriers and Opportunities in Bio-Based Production of Hydrocarbons." Nature Energy 3 (11): 925-35. https://doi.org/10.1101/321067

Zhu, Baotong, Yingying Chen, and Na Wei. 2019. "Engineering Biocatalytic and Biosorptive Materials for Environmental Applications." Trends in Biotechnology 37 (6): 661-76. https://doi.org/10.1016/i.tibtech.2018.11.005 


\section{Appendix}

The following lists the 17 Sustainable Development Goals (SDGs) put forth by the United Nations Department of Economic and Social Affairs to be achieved by 2030 (United Nations 2020). Reprinted with permission.

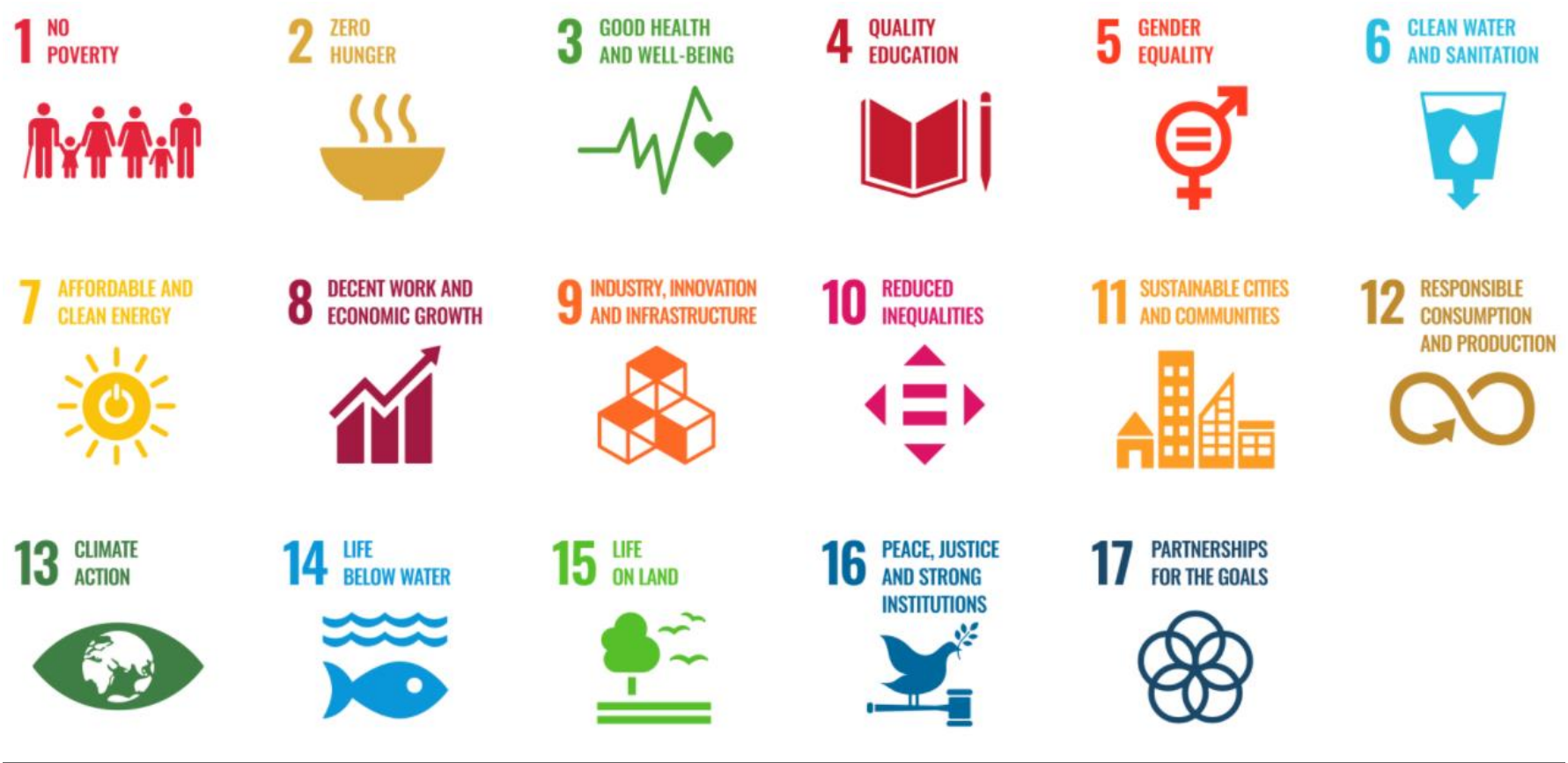

Brendan Grue is currently a medical student at Dalhousie University. Prior to medical school he completed his PhD in Biomedical Engineering at Saint Mary's University. His doctoral research focused on the development of a novel mineralized collagen scaffold for bone repair and regeneration. He has an active interest in scientific policy, communication, and knowledge translation.

Samir Hamadache has an Honors Bachelor of Science in Genetics \& Biochemistry from Western University. As a biochemistry graduate student, his research at the intersection of synthetic biology and automation is aimed at developing new tools for agricultural biotechnology. In addition to being the Vice President of SynBio Canada, Samir is the Founder and President of Forest City SynBio, a startup that is building a Canadian centre of excellence for synthetic biology entrepreneurship and innovation.

Dhanyasri Maddiboina is a $\mathrm{PhD}$ student from McMaster University and her research is at the intersection of engineering and biology. She is investigating the use of bacteriophages (viruses that kill bacteria) for treating infections. Complementary to research, Dhanyasri is heavily involved in mentorship of undergraduate students and in training graduate students in science communication.

Benjamin Scott recently joined the Concordia University Genome Foundry as a Business Development \& Partnerships Engagement Advisor. His post-doctoral and PhD research focused on engineering cellular signaling to develop biosensors for industrially relevant compounds, and to create cell-based therapies. He founded SynBio Canada to strengthen the national research community, to advocate for trainee needs, and highlight their accomplishments.

\section{Acknowledgements}

The authors would like to acknowledge Pierre-Olivier Desmarchais, Avalyne Diotte, Mads Kaern, Jeff Kinder, Evan Larmand, and Rishan Vaitheeswaran for their comments on this publication. 